\title{
Efektivitas Celup Puting Menggunakan Ekstrak Buah Mengkudu (Morinda citrifolia) terhadap Hasil Uji California Mastitis Test (CMT)
}

\author{
T. I. Purwantiningsih", ${ }^{1, *}$ Y. Y. Suranindyah², Widodo ${ }^{2}$ \\ ${ }^{1}$ Prodi Peternakan, Fakultas Pertanian, Universitas Timor \\ ${ }^{2}$ Fakultas Peternakan, Universitas Gadjah Mada
}

\begin{abstract}
ABSTRAK
Tujuan penelitian ini adalah untuk mengetahui efektivitas celup puting menggunakan ekstrak buah Mengkudu (Morinda citrifolia) terhadap hasil uji CMT. Mengkudu mengandung zat anti bakteri, terdiri dari acubin, L. asperuloside, alizarin dan beberapa zat antraquinon yang telah terbukti menunjukkan kekuatan melawan bakteri patogen. Penelitian ini menggunakan empat ekor sapi Friesian Holstein $(\mathrm{FH})$ yang diketahui mastitis sub klinis dan larutan celup puting yang berasal dari buah Mengkudu matang. Puting sapi FH dicelup menggunakan ekstrak buah Mengkudu konsentrasi $30 \%$. Setelah dicelup, dilakukan penggujian Californian mastitis test (CMT). Berdasarkan analisa stastistik T-Test yang digunakan, ekstrak buah Mengkudu secara signifikan $(\mathrm{p}<0,01)$ dapat menghambat bakteri penyebab mastitis. Ekstrak buah Mengkudu mampu menghambat penyebaran bakteri penyebab mastitis sehingga menurunkan resiko terkena mastitis.
\end{abstract}

Kata Kunci: California mastitis test, Celup puting, Mastitis sub klinis, Mengkudu

\section{Effectiveness of Puting Detection Using Multi Cultiver Extract (Morinda citrifolia) on Test California Result of Test (CMT)}

\section{ABSTRACT}

The purpose of this study was to determine the effectiveness of nipple dip with Mengkudu extact (Morinda citrifolia) on CMT test result. Mengkudu contains anti-bacterial substances, consisting of acubin, L. asperuloside, alizarin and some antraquinon substances that have been shown to show strength against pathogenic bacteria. This study used four Friesian Holstein (FH) cows which are known for sub-clinical mastitis and nipple dyeing solution from mature noni fruit. Nipple FH dipped using 30\% concentration of noni fruit extract. After dyed, a Californian mastitis test (CMT) was performed. Based on the stastistic analysis of T-Test used, extract of noni fruit significantly $(p<0,01)$ can inhibit bacteria cause mastitis. Noni fruit extract is able to inhibit the spread of bacteria that cause mastitis, thus lowering the risk of mastitis.

Keywords: California mastitis test, Mengkudu, Nipple dye, Sub-clinical mastitis

\section{PENDAHULUAN}

Mastitis secara umum didefinisikan sebagai peradangan jaringan internal ambing. Peradangan pada ambing ini disertai dengan perubahan fisik, kimia, mikrobiologi dan adanya kenaikan jumlah sel radang (jumlah sel somatik/somatic cell count), terutama leukosit dalam susu dan dapat disertai dengan perubahan patologi pada jaringan ambing, yang disebabkan oleh infeksi dua golongan bakteri yaitu bakteri gram positif dan gram negatif (Sufiriyanto dan Indraji, 2005). Mastitis dapat berlangsung secara subklinis dan klinis. Mastitis dikatakan berlangsung secara subklinis apabila gejala-gejala klinis radang tidak dapat ditemukan pada waktu pemeriksaan ambing. Adanya mikroorganisme dalam ambing yang tidak diikuti perubahan fisik ambing dan susunya dapat dikatakan sebagai infeksi laten (Subronto, 2003).

Mastitis subklinis hanya dapat dideteksi melalui pemeriksaan mikrobiologi dan penghitungan jumlah sel somatik terhadap contoh susu (Sudarwanto, 1998). Metode yang digunakan yaitu metode langsung dan metode tidak langsung. Menurut Sudarwanto dan Sudarnika (2008), metode langsung biasa digunakan

*Penulis Korespondensi: T. I. Purwantiningsih

Alamat: J1. Km 9, Kelurahan Sasi, Kefamenanu, TTU - NTT

E-mail: theresiaicha@gmail.com untuk studi eksperimen dan observasi, dan metode tidak langsung biasa digunakan untuk survey dan program pengendalian mastitis. Beberapa metode tidak langsung yang sering digunakan di lapangan adalah California mastitis test/CMT, whiteside test/WST dan tes IPB-1. Metode tersebut dianggap mempunyai kelebihan, antara lain mudah digunakan, cepat, memiliki kepekaan dan kekhasan yang tinggi. Selain itu juga dapat digunakan langsung di kandang oleh pemerah, tukang kandang, paramedis dan dokter hewan.

Pencelupan puting adalah salah satu cara yang digunakan peternak untuk meminimalisir terjadinya mastitis. Celup puting pasca pemerahan telah banyak dilakukan dan secara luas telah diterima sebagai salah satu perlakuan untuk mengurangi infeksi kelenjar susu (Galton, 2004). Di banyak kawanan ternak, infeksi berkurang ketika celup puting dilakukan. Iodine dan chlorhexidine umumnya digunakan sebagai desinfektan untuk celup puting (Azizoglu et al., 2013). Menurut Subronto (2003), dipping setelah pemerahan dengan chlorine $4 \%$ atau iodium, maupun alkohol $70 \%$ dapat digunakan dalam tindakan pencegahan penyebaran kuman.

Salah satu bahan dari alam yang bisa digunakan sebagai campuran larutan untuk celup puting adalah Mengkudu. Mengkudu mengandung zat anti bakteri, terdiri dari acubin, L. asperuloside, alizarin dan 
beberapa zat antraquinon. Zat-zat yang terdapat di dalam buah Mengkudu telah terbukti menunjukkan kekuatan melawan bakteri patogen, seperti Pseudomonas aeruginosa, Proteus morganii, Staphylococcus aureus, Bacillus subtilis dan Escherichia coli (Kholish, 2011). Ekstrak buah Mengkudu matang memiliki senyawa antibakteri terhadap Pseudomonas aeruginosa, M. pyrogenes, Salmonella typhosa, S. Montevideo, S. schottmuelleri, Shigella paradys, Eschericia coli, Staphylococcus aureus, Bacillus subtilis, Clostridium perfingens dan Vibrio parahaemolyticus. Pada konsentrasi 3.000 ppm menunjukkan aktivitas bakteriostatik terhadap $S$. typosa dan S. aureus (Damayanti dan Suparjana, 2007). Melakukan celup puting dengan ekstrak Mengkudu diharapkan mampu menurunkan hasil uji CMT sehingga dapat mengurangi penyebaran penyakit mastitis.

\section{MATERI DAN METODE}

Penelitian ini menggunakan empat ekor sapi Peranakan Friesien Holstein (PFH) yang terkena mastitis subklinis. Diagnosa mastitis subklinis menggunakan uji California mastitis test (CMT). Penelitian dilakukan di Unit Pelaksana Teknis (UPT) Ternak Perah Fakultas Peternakan Universitas Gadjah Mada, Yogyakarta.

Materi yang digunakan untuk membuat ekstrak buah Mengkudu terdiri dari buah Mengkudu, mesin penggiling (grinder ukuran 60 mesh), timbangan analitik, etanol, kain kasa, waterbath dan air. Materi yang digunakan untuk membuat larutan ekstrak Mengkudu adalah ekstrak Mengkudu, Carboxymethyl Cellulose (CMC), aquadest, magnetic stirrer, erlenmeyer dan timbangan analitik. Materi untuk diagnosa mastitis adalah larutan CMT dan paddle. Materi untuk celup puting adalah larutan ekstrak Mengkudu matang konsentrasi 30\% dan dipper.

Penelitian menggunakan buah Mengkudu sebagai antibakteri alami. Buah Mengkudu dicuci dengan air mengalir (air kran), ditiriskan kemudian dipotong tipis-tipis, kurang lebih $3 \mathrm{~mm}$ dan dioven dengan suhu $50^{\circ} \mathrm{C}$ selama 48 jam. Setelah kering, dihaluskan dengan mesin penggiling (grinder). Serbuk buah Mengkudu yang diperoleh kemudian ditimbang. Serbuk buah Mengkudu yang dihasilkan dimaserasi dengan pelarut etanol 95\% dengan perbandingan 1:7 (setiap 1 gram serbuk Mengkudu, direndam dalam $7 \mathrm{ml}$ etanol) selama 24 jam, sambil sesekali diaduk-aduk. Hasil yang didapatkan disaring dengan kain kasa sehingga diperoleh hasil maserasi cair dan ampas. Hasil maserasi cair kemudian diuapkan di atas waterbath dengan suhu $50^{\circ} \mathrm{C}$ selama 3 hari atau sampai terbentuk gel dan etanol benarbenar menguap. Ekstrak buah Mengkudu yang dihasilkan berupa gel.
Sebelum membuat larutan ekstrak Mengkudu, pertama-tama membuat larutan $0,1 \%$ Carboxymethyl Cellulose (CMC). Sebanyak 0,1 g CMC dimasukkan ke dalam erlenmeyer dan ditambah aquades sampai volume $100 \mathrm{ml}$ lalu dihomogenkan menggunakan magnetic stirrer. Ekstrak Mengkudu matang ditimbang sebanyak $30 \mathrm{~g}$, lalu ditambahkan larutan CMC hingga volume $100 \mathrm{ml}$, kemudian diaduk hingga ekstrak tercampur seluruhnya. Pembuatan larutan ekstrak Mengkudu dilakukan dengan mencampur larutan CMC dengan ekstrak Mengkudu.

Diagnosa mastitis dilakukan dengan mengambil $2 \mathrm{ml}$ susu segar dari setiap puting sapi sampel. Susu tersebut diletakkan di paddle CMT dengan posisi vertikal. Larutan CMT ditambahkan ke masingmasing bagian paddle kemudian paddle CMT diputar, sehingga susu dan larutan CMT tercampur. Proses pencampuran tidak lebih dari 10 detik. Hasil yang terlihat dalam paddle CMT dibaca dengan cepat karena reaksi yang terlihat akan rusak dalam 20 detik. Penilaian reaksi ini secara visual. Lebih banyak gel yang dibentuk, semakin besar nilainya.

Celup puting menggunakan ekstrak buah Mengkudu dilakukan selama sebulan. Keempat puting sapi perah mastitis subklinis dicelup selama 5 sampai 10 detik. Setelah dicelup, keempat puting sapi didiagnosa mastitis kembali untuk melihat apakah ada perubahan yang terjadi.

\section{HASIL DAN PEMBAHASAN}

\section{Diagnosa Mastitis Subklinis}

Hasil pengamatan terhadap mastitis subklinis menggunakan metode California mastitis test (CMT) pada empat ekor sapi ditampilkan pada Tabel 1.

Berdasarkan hasil pengamatan uji CMT yang telah dilakukan, sapi yang digunakan sebagai sampel menunjukkan indikasi mastitis sub klinis kecuali sapi F05 karena hasil uji CMTnya negatif. Puting sebelah kiri depan sapi E51 menunjukkan hasil positif 2 saat pengujian pertama dan pengujian kedua menunjukkan hasil positif 3, puting kanan depan menunjukkan hasil positif 2 saat pengujian pertama dan positif 3 saat pengujian kedua, puting kiri belakang menunjukkan hasil positif 2 saat pengujian pertama dan positif 3 saat pengujian kedua, puting kanan belakang menunjukkan hasil positif 1 saat pengujian pertama dan positif 2 saat pengujian kedua. Puting kanan depan sapi G01 saat pengujian pertama menunjukkan hasil positif 2 sedangkan pengujian kedua menunjukkan hasil negatif, puting kiri belakang menujukkan hasil positif 3 saat pengujian pertama dan positif 2 saat pengujian kedua, puting kanan belakang menunjukkan hasil positif 2 saat pengujian pertama dan negatif saat pengujian kedua. Pada sapi J01, puting kiri sebelah kanan menunjukkan hasil positif 3 saat pengujian pertama dan kedua. 
Tabel 1. Hasil diagnosa mastitis sub klinis menggunakan metode CMT

\begin{tabular}{|c|c|c|c|c|c|c|c|c|}
\hline \multirow[t]{2}{*}{$\begin{array}{l}\text { No. } \\
\text { Sapi }\end{array}$} & \multicolumn{4}{|c|}{ Uji CMT (1) } & \multicolumn{4}{|c|}{ Uji CMT (2) } \\
\hline & PkiD & $\mathrm{PKaD}$ & PkiB & PkaB & PKiD & $\mathrm{PKaD}$ & PKiB & $\mathrm{PKaB}$ \\
\hline E51 & ++ & ++ & ++ & + & +++ & +++ & +++ & ++ \\
\hline F05 & - & - & - & - & - & - & - & - \\
\hline G01 & ++ & ++ & +++ & ++ & ++ & - & ++ & - \\
\hline J01 & +++ & - & - & - & +++ & - & - & - \\
\hline Keterang & $\begin{array}{l}- \\
+ \\
++ \\
++\end{array}$ & $\begin{array}{l}\text { r CMT } 0 \\
\text { r CMT } 1 \\
\text { CMT } 2 \\
\text { r CMT } 3\end{array}$ & & & $\begin{array}{l}\text { PkiD : pu } \\
\text { PkaD : pu } \\
\text { PkiB : pu } \\
\text { PkaB : pu }\end{array}$ & $\begin{array}{l}\text { iri depan } \\
\text { anan dep } \\
\text { iri belaka } \\
\text { anan bela }\end{array}$ & & \\
\hline
\end{tabular}

Hasil negatif pengujian CMT (tidak terinfeksi) ditandai dengan tidak terdapat gumpalan dan sangat encer, trance (sangat ringan dan kemungkinan terjadi infeksi) ditandai dengan adanya gumpalan dan reaksi ini akan menghilang jika paddle diputar lagi, positif 1 (infeksi ringan) ditandai dengan larutan yang mengental akan tetapi tidak condong menjadi gel, jika paddle diputar lebih dari 20 detik kekentalan menghilang, positif 2 (terinfeksi) ditandai dengan terjadi gumpalan dan membentuk gel yang ringan, campuran akan menggumpal di tengah paddle dan akan melapisi bagian bawah apabila dibuang dan positif 3 (terinfeksi kuat) ditandai dengan terbentuknya gel yang sangat kental dan sulit untuk digerakkan (Mellenberger dan Roth, 2000).

Menurut Subronto (2003), proses terjadinya mastitis selalu dimulai dengan masuknya mikroorganisme ke dalam kelenjar melalui lubang puting. Proses terjadinya mastitis dapat dibedakan menjadi beberapa fase, yaitu fase invasi, infeksi dan infiltrasi. Fase invasi adalah fase masuknya mikroorganisme ke dalam puting. Kebanyakan proses invasi terjadi karena terbukanya lubang saluran puting, terutama setelah pemerahan. Invasi mudah terjadi karena keadaan lingkungan yang jelek, populasi kuman patogen yang tinggi dan daya tahan sapi menurun. Fase infeksi ditandai dengan mikroorganisme yang berhasil masuk ke kelenjar akan membentuk koloni yang dalam waktu singkat akan menyebar ke lobuli dan alveoli. Saat mikroorganisme sampai di mukosa kelenjar, tubuh akan bereaksi dengan memobilisasi leukosit. Rusaknya susu akan merangsang timbulnya reaksi jaringan dalam bentuk peningkatan sel di dalam susu. Terbentuknya jonjot fibrin mengakibatkan jaringan mengalami kerusakan. Reaksi tubuh yang berlebihan akan menyebabkan terbentuknya jaringan ikat yang berlebihan, sehingga produksi susu berkurang secara permanen.

Celup puting menggunakan ekstrak buah Mengkudu diharapkan mampu mengurangi kekentalan yang ditimbulkan karena penambahan reagen CMT pada susu segar. Setelah dilakukan perlakuan celup puting menggunakan ekstrak buah Mengkudu hasilnya dapat dilihat pada Tabel 2.

Setelah dilakukan pencelupan puting dengan menggunakan ekstrak buah Mengkudu, terlihat jika terdapat perubahan pada hasil uji CMT. Menurut Subronto (2003), kerusakan jaringan tergantung dari jenis mikroorganisme yang menyebabkan radang, virulensinya dan daya tahan ternak itu sendiri. Selain itu disebabkan oleh proses pemerahan yang tidak apuh, yang ditandai dengan susu yang tertinggal di dalam ambing masih banyak yang tersisa.Perubahan hasil uji CMT sebelum dan sesudah perlakuan celup puting menggunakan ekstrak buah Mengkudu dapat dilihat pada Tabel 3.Menurut Tabel 3, sapi E51 dan sapi G01 mempunyai level penurunan kekentalan pada uji CMT paling besar, yaitu sebesar 2,12 dan 1,13. Menurut Subronto (2003) setelah selesai pemerahan lubang puting masih terbuka untuk beberapa waktu sehingga mudah terkena infeksi. Pencelupan puting dilakukan setelah pemerahan untuk menghalangi masuknya bakteri penyebab mastitis ke dalam ambing. Pencelupan puting setelah pemerahan mengakibatkan penurunan jumlah sel somatik, yang juga akan berpengaruh pada uji CMT. Sufiriyanto dan Indraji (2005) mengemukakan peradangan pada ambing disebabkan oleh infeksi dua golongan bakteri yaitu bakteri gram positif dan gram

Tabel 2. Hasil uji CMT setelah celup puting dengan ekstrak buah Mengkudu

\begin{tabular}{ccccc}
\hline \hline No. sapi & \multicolumn{3}{c}{ Uji CMT } \\
\hline E51 & PKiD & PkaD & PKiB & PKaB \\
F05 & - & + & - & - \\
G01 & - & - & - & - \\
J01 & - & - & + & - \\
\hline Ke & - & - & - & - \\
\hline
\end{tabular}

Keterangan: $+=$ Hasil uji CMT positif $1,-=$ Hasil uji CMT negatif 
Tabel 3. Rata-rata hasil uji CMT sebelum dan sesudah perlakuan

\begin{tabular}{cccc}
\hline \hline No. Sapi & \multicolumn{3}{c}{ Rata-rata hasil uji CMT } \\
\hline E51 & Sebelum & Setelah & Level penurunan \\
F05 & 2,25 & 0,13 & 2,12 \\
G01 & 0,00 & 0,00 & 0,00 \\
J01 & 1,63 & 0,50 & 1,13 \\
Jumlah & 0,75 & 0,13 & 0,62 \\
\hline
\end{tabular}

negatif. Bakteri gram positif tidak tahan terhadap senyawa fenol dan antraquinon. Senyawa fenol dan antraquinon dari buah Mengkudu menekan pertumbuhan bakteri gram positif, karena kemampuan penetrasi senyawa ini dalam dinding sel bakteri. Senyawa fenol dan antraquinon termasuk senyawa yang larut lemak.

Menurut Sufiriyanto dan Indraji (2005), Mengkudu merupakan salah satu tanaman yang mengandung senyawa fenol dan antraquinon pada buahnya yang sangat efektif untuk menekan pertumbuhan bakteri gram positif, karena kemampuan penetrasi senyawa tersebut terhadap dinding sel bakteri. Menurut Damayanti dan Suparjana (2007), fenol merupakan suatu senyawa yang mempunyai cincin aromatik yang terdistribusi oleh satu atau lebih gugus hidroksil, sedangkan antraquinon adalah zat anti bakteri yang merupakan golongan terpenoid dan turunan fenol. Secara umum golongan fenol mampu merusak membran sel, menginaktifkan enzim dan mendenaturasi protein sehingga dinding sel mengalami kerusakan karena penurunan permeabilitas. Perubahan permeabilitas membran sitoplasma memungkinkan terganggunya transportasi ion-ion organik yang penting ke dalam sel sehingga berakibat terhambatnya pertumbuhan bahkan hingga mematikan sel. Senyawa golongan lain yang mempunyai polaritas sama dengan golongan fenol adalah terpenoid. Senyawa terpenoid mampu berikatan dengan lemak dan karbohidrat. Keadaan ini menyebabkan permeabilitas membran sel terganggu. Kerusakan membran juga berakibat pada proses fisiologi dalam sel. Senyawa terpenoid dapat menimbulkan lisis pada sel dan senyawa terpenoid bersifat antibakteri.

\section{KESIMPULAN}

Penggunaan 30\% ekstrak buah Mengkudu sebagai bahan untuk celup puting mampu mengurangi kekentalan pada uji CMT. Hal ini dibuktikan dengan berkurangnya kekentalan uji CMT pada sapi E51 dan G01. Semakin sedikit gel yang terbentuk pada susu yang diuji maka semakin kecil kemungkinan terinfeksi bakteri penyebab mastitis.

\section{DAFTAR PUSTAKA}

Azizoglu, R.O, R. Lyman and K.L. Anderson. 2013. Bovine Staphylococcus aureus: Dose response to iodine and chlorhexidine and effect of iodine challenge on antibiotic susceptibility. Jounal of Dairy Science. 96: 993-999.

Damayanti, E dan T.B. Suparjana. 2007. Efek penghambatan beberapa fraksi ekstrak buah Mengkudu terhadap Shigella dysenteriae. Prosiding Seminar Nasional Tehnik Kimia "Kejuangan". Yogyakarta.

Galton, D.M. 2004. Effect of an automatic postmilking teat dipping system on new intramammary infections and and iodine in milk. Jounal of Dairy Science. 87: 225-231.

Kholish, N. 2011. Bebas Hipertensi Seumur Hidup dengan Terapi Herbal. Realbooks. Yogyakarta.

Mellenberger, R and C.J. Roth. 2000. California Mastitis Test (CMT). Fact Sheet.

Subronto. 2003. Ilmu Penyakit Ternak. Gadjah Mada University Press. Yogyakarta.

Sudarwanto, M dan E. Sudarnika. 2008. Hubungan antara $\mathrm{pH}$ susu dengan jumlah sel somatic sebagai parameter mastitis subklinik. Media Peternakan. 31(2): 107-113.

Sudarwanto, M. 1998. Pereaksi IPB-1 sebagai pereaksi alternatif untuk mendeteksi mastitis subklinis. Media Veteriner 5(1): 1-5.

Sufiriyanto dan M. Indraji. 2005. Uji in vitro dan in vivo ekstrak campuran Mengkudu (Morinda citrifolia) dan bawang putih (Allium sativum) pada sapi perah penderita mastitis sub klinis. Animal Production 7: 101-105. 